\title{
LETTERS
}

\section{In defense of Canada's drug plan managers}

In a recent article, Morgan and Persaud criticize Canada's drug plan managers for a recent extension of a generic drug pricing agreement. ${ }^{1}$ They explain that New Zealand has lower generic drug prices than Canada and propose that Canadian provinces should employ a tender system, like New Zealand's, to get the same low prices. Unfortunately, they don't seem to appreciate why Canada uses a different system for pricing generic drugs. Morgan and Persaud vaguely accuse the provinces of succumbing to pressure from pharmacies and manufacturers (which, they allege, have hundreds of millions of dollars in profits at stake) or of political cowardice.

The problem is that they propose importing one component of an entire system. Possibly we could try to replicate the overall New Zealand system in Canada, but that would be a much larger project. Just trying to mimic one part of the New Zealand model won't generate New Zealand's outcomes.

Morgan and Persaud point to the case of atorvastatin, a blockbuster drug that sells for around $\$ 0.22$ per $20 \mathrm{mg}$ pill in Canada and \$0.02 per pill in New Zealand. The case of atorvastatin is a particularly apt example: why didn't Canada just use the same tendering process to get low prices for atorvastatin? I can offer an answer: if Canada had set up a tendering process for atorvastatin, we would still be paying full price for the branded product Lipitor, and no generics would be available at all. Instead of saving money, we would be paying about 10 times as much.

In New Zealand, the government buyer strongly restricted sales of Lipitor from the time of its introduction, and so Pfizer, the patentee, never made much profit there. This was part of a money-saving strategy limiting the set of drugs covered by New Zealand's national insurance plan. Because New Zealand is willing to not insure many drugs commonly used by Canadians, it can bargain aggressively for low prices. Pfizer, rather than fighting to maintain an unprofitable franchise, abandoned many of its atorvastatin patents in New Zealand, effectively enabling generic entry in 2010. As soon as generic entry occurred, the New Zealand government opened up coverage for atorvastatin to everyone for whom it was indicated, showing that the motivation for restricting access to atorvastatin was financial, not clinical. $^{2}$

In Canada, rightly or wrongly, Lipitor was reimbursed by all of the provincial health plans, and Pfizer was strongly motivated to maintain its extremely lucrative monopoly. It filed many, many patents on Lipitor in Canada; some of those listed on the Health Canada Patent Register will not expire until 2022. In these circumstances, entry in Canada could occur only if a generic manufacturer was willing to invest in developing a noninfringing alternative, or to litigate to show that the extant patents were invalid.

This is exactly what happened: Apotex developed a new formulation that it believed did not infringe Pfizer's remaining patents. It claims to have spent "many millions" of dollars on this project. ${ }^{3}$ After working through all of the regulatory and litigation hurdles, Apotex's product was approved by Health Canada and entered the market in May 2010. Pfizer sued Apotex for patent infringement, presumably for hundreds of millions of dollars (see Apotex v. Pfizer, 2014 FC 876). (The infringement suit was no idle threat: Apotex has recently paid hundreds of millions in damages on other products when it was found to have infringed valid patents; e.g., Merck v. Apotex 2013 FC 751.)

Once Apotex had cleared all the relevant hurdles, Pfizer made no objection to other generic firms entering the market, which they did. In these circumstances, one has to ask why Apotex made the investment into opening up the market, at considerable financial risk. The motiva- tion was presumably that it could obtain damages for being kept out of the market; these damages, of course, would be based on predicted losses from the time that Apotex was delayed from entering the atorvastatin market.

What would have happened if, as in New Zealand, all of the provinces ran a tender to purchase atorvastatin as soon as generics became available? The lowest-priced manufacturer would have won, and that would not have been Apotex, given its substantial potential infringement liability. The result is that Apotex would have made no sales, and generated no profits, and may have had no claim for damages. It may well never have considered investing millions of dollars to open up a market from which it would earn nothing. Without Apotex's investment, Canadians would likely still be paying the brand price of $\$ 2.28$ a pill for atorvastatin $20 \mathrm{mg}$ tablets.

The drug plan managers who made the current pricing agreement are neither easy marks for industry lobbyists nor cowards who are fearful of unnamed political risks: They just understand that Canada isn't New Zealand. Canada has a very different market, with about 10 times the population, higher incomes, much less restrictive formularies, and strong pricing pressures from the United States. Just trying to match pricing, without acknowledging differences in institutions and incentives, is rather like proposing that Canada should also reduce physician salaries by $46 \%$, to New Zealand levels. That would save a lot of money, but patients might object when they discovered that their doctors had fled the country. 4,5

Tendering has real advantages, but it needs to be used judiciously; there are certainly opportunities to apply it to products that have been generic for many years. The agreement recently made by the drug plan managers balances the need to get low prices on existing generic drugs with the need to ensure that currently patented drugs become available 
generically in a timely manner. The drug plan managers are right to design a pricing structure that is sensitive to Canada's institutions and circumstances.

\section{Aidan Hollis PhD}

Professor of economics, University of Calgary, Calgary, Alta.

Cite as: CMAJ 2018 June 25;190:E771-2. doi: $10.1503 / \mathrm{cmaj} .69951$

\section{References}

1. Morgan SG, Persaud N. New generic pricing scheme maintains high prices and risks of shortages. CMAJ 2018;190:E410-1.

2. Pharmac. Open access follows price reduction for cholesterol drug [media release]. Auckland: Pharmaceutical Management Agency; 2010 June 18. Available: http://pharmac.govt.nz/2010/06/18/ Atorvastatin generic funded.pdf (accessed 2018 May 13)

3. Apotex overcomes Lipitor drug patents saving healthcare system billions of dollars [media release]. Toronto: Apotex; 2010 May 19. Available: www.apotex.com/ca/en/about/press/20100519. asp (accessed 2018 May 13).

4. Picard A. How much are Canadian doctors paid? The Globe and Mail [Toronto]. 2013 Jan. 23

5. Clayton R. Demand for doctors sees their salaries rise. Stuff.co.nz 2017 Aug. 28. Available: www.stuff. co.nz/business/96161857/demand-for-doctors-sees -salaries-rise (accessed 2018 May 13)

Competing interests: Aidan Hollis reports personal fees from Apotex and personal fees from the Canadian Generic Pharmaceutical Association, outside the submitted work. 